\title{
Discussion on Life Safety Education in Colleges and Universities Under the Moral Concept of the New
}

\author{
Era*
}

\author{
Liguang Zhao \\ School of Taxation \\ Jilin University of Finance and Economics \\ Changchun, China 130117
}

\author{
Mingju Liu \\ Yatai School of Business Administration \\ Jilin University of Finance and Economics \\ Changchun, China 130117
}

\begin{abstract}
This paper focuses on the study of life safety, discusses briefly the present situation of life safety in our country, seeks for the connotation of the combination of times morality and life safety, and analyzes the influence content of life safety education in colleges and universities from the angle of inheritance, development and advance. Then between life safety education and moral idea of the new era are discussed from four aspects: the life cognition system of the inheritance age, the attention to the life practice guidance of the body angle, the life morality of the mind and the life ideal system of constructing the realistic angle.
\end{abstract}

\section{Keywords—new era; moral concept; college; life safety}

\section{INTRODUCTION}

Colleges and universities shoulder the important task of cultivating reliable constructors and qualified successors of socialist cause. Therefore, the construction of harmonious campus and the education of ideal and belief for young students have become the important contents of moral education and ideological and political education in colleges and universities. However, in recent years, suicides, homicide, cruelty and killing of animals, violence on campus, natural disasters with sudden irresistible force and man-made injuries have increased in recent years, and at the same time, it also makes young students confused and confused about their outlook on life and values. In the new era, the development of economy, the improvement of people's living standard, the change of life style, the change of thinking mode and the infiltration of foreign organizations make the life safety education of colleges and universities face severe challenges. How to make use of the connotation of the new era spirit of the moral idea, guide the students' life safety thought, realize the college students cherish the life, respect the life, form the fine

*Fund projects: Key issues in the Thirteenth Five-Year Plan of Educational Science in Jilin Province (ZD17073); General topic of the Thirteenth Five-Year Plan of Educational Science in Jilin Province (GH170329); The thirteen Five-Year social science research planning project of the Jilin Provincial Education Department, "College Counselors in the new era to carry out the research on the emergency treatment of students' safety events", the key project of the basic party building innovation of the Jilin University of Finance and finance in 2017 and the stage research results of the key project of the counselor of Jilin University of Finance and economics. character, and realize the progress of the quality ability and physique. Therefore, to promote the overall development of college students' overall quality has become an important research content of cultivating talents.

\section{ThE PRESENT SituATION OF LIFE SAFETy EDUCATION}

The earliest life education was first put forward in 1968 by Jaydowner Watts of the United States. In 1979, Australia established a "life education center." the life education of our country was first introduced in Hong Kong, China, and in Taiwan, in the 1990s,life education in Hong Kong revolved around life, with love as the core to enable students to recognize themselves, affirm themselves and realize themselves. Taiwan, on the other hand, derived from unhealthy health behaviors among young people.

In the 1990s, the Chinese mainland began to have some educational thinking and local exploration, and then life education gradually became a hot topic of common concern among the educational circles, philosophy circles and social circles in mainland China. At the same time, some college scholars are paying attention to the philosophy of death and offering related courses. For example, Duan Dezhi set up "philosophy of death" course in Wuhan University, Zheng Xiaojiang started "philosophy of Life and death" course in Nanchang University in 1994; Since 2006, Jiangxi normal University has offered a public elective course, "philosophy of Life and death and Life Education," and later academic forums on life safety education in sports, life education in medicine and life education for teenagers, etc. Therefore, to a certain extent, people understand and pay attention to life and death and life problems.

At the national level, in 2004,"Opinions of the CPC Central Committee and the State Council on Further Strengthening and improving the ideological and moral construction of minors "was promulgated. The education departments of Liaoning and Shanghai first carried out life education courses in primary and secondary schools. There are many other social groups that have contributed to the situation, and then many colleges and universities, middle and primary schools have begun to try to offer life education courses. In 2010, chapter II of "the outline of the National Medium-and Long-term Education Reform and 
Development Plan (2010-2020) "clearly stated: "attach importance to safety education, life education, national defense education, sustainable development education. To promote the organic integration of moral education, intellectual education, physical education and aesthetic education, to improve the students' comprehensive quality, and to make the students become socialist builders and successors for the all-round development of morality, intelligence, sports and beauty. "

Although life education has been studied and practiced for many years, it has also made great achievements, but generally speaking, the essence, meaning, goal, content, way, curriculum system and practice mode of life safety education for college students have not yet been unified, so it is of great significance to study the influence of the moral concept of the new era on the life safety education in colleges and universities.

\section{THE SPIRIT OF THE TIMES OF MORAL CONCEPT AND THE EDUCATION OF LIFE SECURITY}

The moral idea presents the situation of "origin and development" in the angle of life safety education. Life is the physiological basis and carrier of moral existence. When the two moral behaviors we produce in society can be classified as higher spiritual activities of human beings, therefore, in the perspective of moral norms, life is respected, and morality is the product of human development. According to Maslow's demand theory, morality is above the need of security, "morality is based on life, and in a sense higher than life."

For more than two thousand years, the traditional moral norms, which have taken "benevolence, righteousness, propriety, wisdom, and faith" as the basic moral requirements, have long dominated, "the unity of nature and man," and "benevolence, full of compassion.""filial piety, loyalty" and so on have the explanation about the life, therefore has produced the huge influence to the people's social life, therefore we cannot be difficult to discover the life education may rise to the thought domain, the moral domain, with the pace of socialism with Chinese characteristics in the new era, the moral concepts of the new era, such as the socialist core values with the spirit of the times and the moral norms of citizens, have once again affected the student groups in colleges and universities with new connotations.

The moral concept of the new era condenses the excellent Chinese traditional culture, carries out from the angle of citizen morality, and takes serving the people as the core, collectivism as the principle, honesty and trustworthiness as the emphasis, and widely developing social morality. Professional ethics and family virtue education, on the basis of tradition, with the people as the core to determine the direction, combined with Marxist ethics, forms the unique innovation and moral inheritance of socialism with Chinese characteristics, on the basis of this, college students can learn to respect life, understand the meaning of life and the relationship between life and nature, and actively survive through the spirit of the times of moral concept to realize that the individual faces life and death directly, healthy to live, independent to develop, but also to grasp the knowledge of safety to protect life, the ability to cope with the crisis, so as to achieve the greatest value of their own life and the greatest ability to live.

\section{INFLUENCING FACTORS ON LIFE SAFETY COGNITION OF COLLEGE STUDENTS GROUP}

\section{A. Lack of Reverence for the Continuation of Life in Inheritance}

The theoretical system of knowledge in colleges and universities is formed slowly in the course of years of development and collision. Many also include the merger of China and foreign countries. However, as a country with a history of 5000 years, life education also existed in various theories. As a group of college students, they should master and study. However, due to the changes in educational methods and personal minds, many people forget their excellent moral theory and traditional culture. The pressure of studying, working, and living is everywhere. The moral content of "benevolence, honesty, filial piety and love for the elderly" should become a value that has been infiltrated for a long time in our daily life. It is a value that is "dreaded but not presumptuous to succeed in virtue, and fearless to suffer from its desires", to be respectful, to worship, to pursue,; there is fear, only know what to do, what not to do. Without fear, there would be no spiritual backing and no motivation to move forward. On the contrary, there is a lack of respect and respect for the continuity of life in colleges and society, among college students, such as suicide, homicide, cruelly and killed animals, campus violence, natural disasters with sudden irresistible force, man-made injuries, and so on, such as the Ma Jia Jue case in Yunnan, the Lin Senhao poisoning case of Fudan University Medical School, and the homicide case of Yao Jiaxin, Xi'An Conservatory of Music, in the car crash, there are also some cases of neglect and neglect at the moment of life and death in society, as well as cases in which compatriots of foreign students have been maimed or killed, these are all incidents that have taken place as a group with a higher education level, these disregard for life has become more prominent in recent years.

\section{B. Lack of Understanding of the Meaning of Life in Development}

Without the fear of life, many people will not pursue the meaning of life naturally, so that no one cares about life in ordinary life. Since the 90 s of last century, China has been in a period of social transformation, and the market economy has been developing rapidly. This change has a profound influence on the members of the society, it is also the post - 90 and 00 young people born in this period who have been affected by different effects, coexistence of good and bad, and full of challenges and threats. The development of the market economy has an undeniable and great positive effect, at the same time, there is also a negative side, and the life and behavior of the college students are also affected, not only in the interests of the light of the indifference to life security, but also to seek an angle of exciting and profit from the perspective of life, for example, such as the murder of animals to seek stimulation, the illegal sale of organs in profit making, the blind pursuit of extravagant illegal Internet loans, all of which have an impact on the life safety of college students.

With the rapid development of network technology, the original slow information transmission has become real-time 
information release, the development of many high-tech industries has also caused problems in life safety aspects, such as online games and video files, it contains the death, killing and other contents of highly simulated situations. In the course of the operation of the playman, the immaterial imprint of his mind is indifferent to the safety of life, and the highly simulated VR technology is used by the illegal merchants, all of which lead to the emergence of the problem of safety of life, what is more affected is the group of junior high school students and college students who like to be in touch with new things.

Because the life safety education of our country started in the 1990s, but the speed of development and attention is slow, the content of life safety education for college students is still weak, some colleges and universities have set up life safety courses, however, compared with the whole country, it is still lacking, which leads to the lack of college students' attitude to life safety, their willingness to live safety and their awareness of life safety, at the same time, because of the limited effect of life safety education in schools, therefore, students generally do not pay enough attention to life safety, nor do they study and appreciate the significance of life.

\section{The Practice of Lacking Source of Life in Advance}

In the development of the times, the cultivation of talents should be a combination of knowledge and practice, which is part of the traditional morality, as the angle of life safety education, we should advocate practice, recognize life from practice, and explore the significance of life, however, as most college students are mainly one-child students, they are spoiled in the process of growing up, and parents' demands for children are obedient, responsive and indulgent. At the same time, the children who grew up in such an environment could not withstand setbacks and stimuli. They were overwhelmed and complained by difficulties that they would also have a disregard for the safety of their lives. At the same time, For a long time, our country is in the "exam oriented and cramming" education for the purpose of entrance examination, which leads to the lack of quality education and moral education in junior high school education, the lack of social practice and the practice of life safety. Thus affecting the education of life safety, some college students' psychological quality is poor in the new period, when they encounter people and things that are not satisfactory, they panic, fall into bad mood and cannot extricate themselves, and sometimes use extreme means, cause serious consequences.

At the same time, in the process of social and economic transformation, we are also under the impact of foreign multiculturalism. Under the influence of global sharing of network information, contemporary college students are receiving various social, political and cultural trends of thought infiltration and rendering in the network environment. These factors have a profound impact on their growth and success. The value choice of contemporary college students in China tends to be pragmatic and pluralistic, with a strong utilitarian color. Some college students questioned the spiritual value of giving priority to public interests and giving up selflessness, more and more college students accept extreme individualism, utilitarianism and hedonism, these factors are impacting the ideology of the student group, the point of view of moral philosophy is at stake, which in turn affects the safety of life, for example, some countries want to control our youth generation through thought, and do anti-life things through such channels as the Internet, Wechat, etc, such as Video of killing human beings and animals, anti-social remarks by extremist groups, and the "blue whale game" that once appeared in WeChat circle have all seriously influenced and induced some student groups to recognize life.

\section{NEW IDEAS OF LIFE SAFETY EDUCATION IN COLLEGES AND UNIVERSITIES UNDER THE NEW ERA MORAL CONCEPT}

\section{A. Life Cognition System from the Angle of Inheritance}

A man without virtue is not standing, a country without virtue does not rise, as the talents needed in the development of the new era, colleges and universities are shouldering such a mission, from the angle of inheritance and development, we should regard the core values of socialism as the basic standard, through these, we can improve the students' cognition of life, refine the cognitive content of life in traditional morality, give play to the freedom, equality and honesty of the socialist core values, educate students, recognize life, and fear life, only in this way can the function of moral idea be brought into play.

\section{B. Focus on the Body Angle of Life Practice Guidance}

Under the guidance of the moral concept of the new era, we have changed our attention to the life practice of the body angle of the student group. In the life safety education in colleges and universities, we should not only teach the students the theory, but also, more importantly, witness and understand the life through the practice, we advocate that "unity of knowledge and action" will help students and colleges establish a harmonious channel of communication. When college students are faced with no longer boring theoretical knowledge, they will be touched by their senses and hearts and put into practice. For example, it is necessary to establish a reasonable economic outlook and values, not to do anything harmful to life, to reject illegal Internet loans, and to protect the privacy of individuals reasonably. If they are not handled properly, the safety of their lives will be affected. There are a lot of life security incidents in society due to the huge amount of money owed by the Internet loan, so we have to use the socialist core values system to guide the freedom, equality, and justice of the society, in order to improve the connotation of life safety education in colleges and universities, the legal system should supervise and remind the students on the network, and establish a reasonable way of moral education on the network so as to improve the consciousness of life safety of the students.

\section{Establishing the Moral Concept of Life from the Perspective of Mind}

Life safety education in colleges and universities should be carried out at different levels and from different angles according to the actual situation. We should give full play to the excellent traditional moral culture of China, combine with the development of the times, and grasp the ideological requirements of reality. Let students not only have practice, but 
also form spiritual and ideological insights in practice, such as psychological guidance in colleges and universities, the construction of a culture of love and good faith, and guidance for employment and entrepreneurship. Even in the education of poor family students, life morality can be integrated into it. Therefore, life morality should be formed to help students improve their ability to understand and respect life, and at the same time to guide people to cherish life and care life, the first thing to solve in this process is the ideological problem, thought is the guide to behavior, correct thinking produces correct behavior. Chinese traditional culture is the moral source for the growth of new youth in the new era. In order to improve the moral self-discipline consciousness and moral practice ability of young people, we must "dig deeply into the ideological concept, humanistic spirit, moral standard contained in Chinese excellent traditional culture, and combine with the requirements of the times to inherit and innovate, let Chinese culture show permanent charm and style of the times."

\section{Constructing the Ideal System of Life from the Perspective of Reality}

Life safety education in colleges and universities is of great significance to the growth of student groups, it not only relates to the safety of students, but also to the all-round development of socialism in the new era, learn the moral concepts of "do not impose on others what you do not want to do,""Love the crowd, the pro benevolent, and inherits the values and moral norms left by their predecessors, and then achieves the goal of "to educate people by culture, to cultivate people by culture", in campus culture, they learn to be kind to life and learn to praise and appreciate life, these are the components of the guiding system for actively constructing life ideals at the social, university, family, and individual levels. The ideal of life should be based on the national spirit of patriotism as the core and the spirit of the times at the core of reform and innovation as the main line, in order to make the life safety education in colleges and universities melt the moral essence of the times and become the life safety ideal of the times, we should dig into and expound the value of the Chinese excellent traditional culture of stressing benevolence, attaching importance to the people, keeping good faith, upholding justice, remaining in harmony with each other and seeking the same as one.

\section{CONCLUSION}

Under the atmosphere of upholding Marxist morality and socialist morality in the new era, the new era is based on ideals and beliefs, guided by socialist core values, adheres to creative transformation, innovative development, and adhering to the Chinese cultural standpoint and inheriting Chinese culture genes, we should stick to the moral concept and internalize it in the mind and outside. These contents are the spiritual inheritance and extension of the moral idea in the new era, and these contents have important guiding significance to the life safety education in colleges and universities.

\section{REFERENCES}

[1] Zhao Liguang Viu Mingju,An Analysis of the influence of honesty and Love Culture on the cultivation of talents in Financial and
Economic Colleges and Universities[J],"Green Technology",2015 (12) : 325-326. 赵黎光、刘明菊,财经类高校诚信和爱心文化对人才 培养的影响分析[J], 《绿色科技》,2015 (12):325-326.

[2] Zhang Dainian.Life and morality[J].Journal of Peking University (philosophy Society Edition),1995,(5):31-32. 1. 张岱年.生命与道德 [J] 北京大学学报(哲社版),1995,(5):31-32.

[3] Jin Peng,A study on the function of moral Education in Life Education in Colleges and Universities[D],Liaoning University,2014. 金鹏, 高等学 校生命教育的德育功能研究[D],辽宁大学,2014

[4] Zhao Liguang,An Analysis of the influence of honesty and Love Culture on the cultivation of talents in Financial and Economic Colleges and Universities[J],"Green Technology",2016 (19):144-145. 赵黎光,优 秀传统文化对财经类高校学生就业观影响分析 [J], 《绿色科 技》,2016 (19) :144-145

[5] A study on the Application of the "Rule" of Love Education such as Zhao Liguang and Zhu Lirui in the work of subsidizing the Poor students in Colleges and Universities[J],"Enterprise cultureperiodical appearing once every ten days", 2012 (9) :128-128. 赵黎光、朱丽芯等 爱心教育 “法则” 在高校贫困生资助工作中的应用研究 $[\mathrm{J}]$, 《企业 文化旬刊》, 2012 (9) :128-128

[6] Liu Binzhi,Liang Jinlian,Review and Prospect of the Research on College student' Life Education in the past Ten years[J],Juvenile Journal,2018（1）:31-37. 刘斌志,梁谨恋,近十年来大学生生命教育 研究的回顾与前瞻[J],青少年学刊,2018 (1) :31-37

[7] Hu Jingxian,Research on Life Safety Education of College students based on Mobile Internet[J],Journal of Heihe university,2017 (7) : 32-33. 胡静娴,基于移动互联网的大学生生命安全教育研究 [J], 黑河 学院学报,2017(7) : 32-33 